\title{
Impact of Public Expenditure on the Growth in Morocco: Role of Governance
}

\author{
Tlaytmaste Bahaddi ${ }^{1} \&$ Mohamed Karim ${ }^{1}$ \\ ${ }^{1}$ EREMEFP, University of Mohammed V, Rabat, Morocco \\ Correspondence: Mohamed Karim, University of Mohammed V, Rabat, Morocco. Tel: 212-6618-3260. E-mail: \\ xmedkarimx@gmail.com
}

Received: January 25, 2017

Accepted: February 20, 2017

Online Published: March 10, 2017

doi:10.5539/ijef.v9n4p12

URL: https://doi.org/10.5539/ijef.v9n4p12

\begin{abstract}
The objective of this study is to evaluate the effect of the public expenditure on economic growth in Morocco and to assess the quality of governance impact on public spending by using the Error Correction Model following the approach of Johansen. In the light of the results of the econometric regression, good governance remains the best option that allows the Moroccan government to achieve considerable macroeconomic performance. In fact, the budgetary component of total public expenditure has a long-term positive impact on the economic activity. It can be a good strategy for Morocco to invest in governance, which proves to provide low-cost long-term benefits. Overall, good governance improves the effectiveness of the budgetary policy and exerts a positive and significant effect on economic activity in Morocco.
\end{abstract}

Keywords: fiscal policy, governance, growth

\section{Introduction}

The recession has weakened the public finances of most of the country. The plans of recovery, the contraction of tax revenue, a high unemployment: such are some of the factors that have led to historically high levels of deficit and debt of the public administrations.

The consolidation of public finances and the reduction of the public debt relative to the size of the economy are challenges which are even more important in the context of the aging of the population. These demographic trends will only accentuate the pressure on the public finances. It is, therefore, appropriate to correct the budgetary deficits and to carry out coherent policies in time before the aging of the population does not result in an increase in public expenditure.

The State having to Only tool the fiscal policy and must not abuse it but, must effectively manage and therefore control the effect that can have the public expenditure on economic activity because the spending too high can exert pressure on the conduct of economic policy and bias the progression of the growth.

Several questions then arise. The first, decisive, is about the effectiveness of the fiscal policies. Blanchard and Perotti (2002), then Perotti (2002), have revived the debate on the effectiveness of the fiscal policy in proposing an assessment of its dynamic effects on macroeconomic variables, in particular on the GDP.

It is as well as the authors have tried to analyze the role of public expenditure in the economic growth of a country to the help of endogenous growth model of Solow taking into account the baskets of qualitative and quantitative variables (Agenor, 2002). Baldacci, Clements, Gupta, Hillman, and Kojo (2003), not gouan, K. P. (2013) offer the need to take account of the aspects of the governance in the research of the effectiveness of the budgetary variables on growth for countries (low income) supported by the IMF.

In Morocco, this exercise has been carried out in different ways. However, the recent aspects of the governance and their influence on the relationship between public spending and growth remain without response in the framework of the Moroccan economy.

Indeed, the recent developments in the world economy have shown how important it was for an economy to promote efficient management and sparing of public expenditure. In particular, the inadequacy of resources in the developing countries should bring the Governments concerned to pay greater attention to the quality of public expenditure. 
The present study attempts to respond to the fundamental question, what is the effect of public expenditure on economic growth in Morocco? This study seeks to assess the influence that has exercised the budgetary policy on the pace of economic activity in Morocco while incorporating the role of governance in the search of its effectiveness.

The article is structured as follows. In section 2, we present a brief review of the literature on the theoretical links existing between public spending, the economic growth, and governance. In section 3 , we clarify the data and the methodology used. Section 4 presents the results of the estimation. Section 5 is devoted to the conclusion.

\section{Review of the Literature}

This point presents a review of theoretical literature of the existing link between public spending, economic growth and governance.

\subsection{Public Spending and Economic Growth}

The fiscal policy has long been perceived as an instrument of regulation of economic activity in the face of shocks. It has taken its importance with J.M. Keynes and he exposes the transmission channels in his famous book entitled "General Theory of Employment, Interest, and Money", published in 1936. It stipulates that the investment is a component of the demand and it is by this means that it is a factor of growth: the public spending is an exogenous factor which can be used as a variable of the policy, and which may have an impact on the growth and development in the short term.

The detractors of the Keynesian theory, including the neoclassical, challenged the virtuous effect of public spending and argue that the expansionary fiscal policy has no favorable effects on the economic activity.

For David Ricardo (1817), the budgetary policy may prove to be ineffective due to the rational expectations and carried out by economic agents: finance public expenditure by a tax increase or by a loan amounts to the same thing, because in the second case, households anticipate a future increase in taxes to repay the debt, and therefore save the extra income distributed. The effects of the budgetary expansion are therefore canceled by the expectations of economic agents. This is the principle of Ricardian equivalence.

On the other hand, the thought accepted by Wagner (1890) (the act of Wagner) said that public expenditures is an endogenous factor which is determined by the growth of the national income. Three explanations are advanced by the author.

The first explanation is that the process of industrialization brings the social progress since it generally increases the income requiring new forms of organization of the collective life, causing expenditures increased in government consumption.

The second cause of the increase in the activities of the public sector is the elevation of the level of life. The State must satisfay new needs of collective services necessary for the formation of human capital (culture, basic education, training of workers, social action, and health).

Finally, industrialization requires significant investments that their realization returns to governments (transport, telecommunications...).

In the years 1980, the role of the public investment in the long-term economic growth is relayed by the proponents of the theory of endogenous growth. In their formalization, several models of endogenous growth exist, depending on the engine of growth.

- The first, as a result of Paul Romer, says that the engine of growth (the residual factors) comes mainly from the accumulation of knowledge and technological capital due to innovation and research and development;

- The second directorate opened by Lucas (1988), favors the accumulation of human capital, as the engine of growth;

- The third direction opened by Barro (1990), takes into account the expenses of public infrastructure (public capital), as the engine of growth;

Throughout its development, the theory of the growth is interested to variables such as the work, the capital (physical or human) and the technical progress and to the way in which the factors are combined between them to explain the differences in growth between countries. However, there are still differences in growth between developed and developing countries but also within developing countries. The reflection is then brought to the institutional determinants and policies to explain growth. 


\subsection{Governance and Economic Growth}

Kaufmann, Kraay, and Mastruzzi define the governance as the set of traditions and institutions by which the authority is exercised in a country.

The economic literature has given attention to the institutions that recently, in the 1990s, and particularly with the work of Douglas North $(1989,1990)$, which shows that better institutions and a better protection of property rights increase investment and stimulate the technical progress and therefore the income. The good institutions encourage investment in the equipment, the human capital, and the technologies and, accordingly, economies grow .

The institutions are considered to be among the qualitative factors of growth and development. North (1990) affirms that: "The countries of the third world are poor because the institutional constraints that define a set of heavy costs on the economic policies do not encourage the economic activity which does not encourage the productive activity".

The policy of public spending cannot be effective without an institutional support - policy and administrative solid. When the institutional quality is poor, the Executive has a margin of maneuver more important in the allocation of public funds. The structure of public expenditure then tends to be biased in favor of those that generate the most profit policies and those valued by the leaders. Our argument is based on the model of politico cycle-budgetary Drazen and Eslava (2005a).

The system policy must ensure the judicious distribution of public expenditure. The budget transparency and accountability of public authorities allow the mobilization of the population in favor of public programs productive. Thus, the follow-up of the citizens of the government programs can help to reduce waste due to corruption and to the search for an annuity.

Finally and most importantly, it should not be forgotten that it is important to use the mechanisms of the market to properly manage expenditures. For example, an efficient system of procurement allows you to effectively ensure the provision of public goods and services.

\section{Methodology}

\subsection{Model}

We will estimate the relationship between the composition of expenditures and the growth in performing a regression of real GDP on a set of explanatory variables, including budgetary variables, the variables of the governance as well as other control variables. The method appropriate would be to estimate a Vector Error Model (VECM) which has the property to determine the relationships of a long and short term between the variables.

Our model corresponds to the following specification:

- In order to identify specific impacts on the growth of the components of public expenditure, a simple disaggregation has been performed, to isolate Government consumption expenditure (GC) on investment expenditure (INV), all other things being equal:

$$
R G D P_{t}=\alpha_{0}+\alpha_{1} G C_{t}+\alpha_{2} I N V_{t}+\alpha_{3} I R P_{t}+\alpha_{4} I T_{t}+\alpha_{5} I N F L_{t}+\varepsilon_{t}
$$

Where RGDP is the real gross domestic product; GC are the government consumption expenditure; INV are the investment expenditure; IRP is a variable capturing the governance on the economic situation, it is the index of risk policy; IT is the rate of interest; INFL is the rate of inflation.

\subsection{Data}

The data used for the estimation are annual and available from 1980 to 2012. They are obtained from the HCP (ministry of Plan). As for the interest rate is available at the database of central bank. The indicator of the governance (IRP) is produced by the International Country Risk Guide (ICRG) and cover the period 1984-2012.

The main indicators used to measure the quality of institutions are the Composite indicators of governance of the World Bank, the indicators of the International Country Risk Guide (ICRG), the indicator of perception of corruption (CPI) of Transparency International and the indicators of political rights and civil liberties of Freedom House. As far as we are concerned, we use the indices of risk policy of the International Country Risk Guide (ICRG).

The evaluation of the risk policy of a country is based on a set of indicators, namely: the stability of the Government, the socio-economic conditions, the quality of the investment, the internal and external conflicts, corruption, the participation of military forces or of the army in the policy, religious tension, the respect of the 
Act as well as the soundness and the impartiality of the judicial system, democratic accountability and the quality bureaucratic.

The real variables "GDP", "GC", "INV", and "IRP" in this model are expressed in curved logarithmic form so that their coefficients in the estimated model can be interpreted like elasticity's.

Our analysis will begin by performing the stationarity test of different variables. Then we will test the existence of the cointegration relations before examining the causality between variables. At the end, we will carry out an impulse analysis by calculating the functions of answers to shocks.

\section{Results}

\subsection{Unit Root Test}

The analysis of the stationarity is a prerequisite to meet to avoid spurious regressions. For this, we will apply the test of Augmented Dickey Fuller on each series.

The tests of Dickey -Fuller are a parametric tests allowing to highlight the Stationary character or not of a chronic. They help us to determine the degree of stationarity (order of integration) of the variables.

The test of stationarity is represented in the table below:

Table 1. Augmented Dickey-Fuller test

\begin{tabular}{lcccccc}
\hline & \multicolumn{3}{c}{ Level variables, } & \multicolumn{3}{c}{ Stationary variables } \\
\cline { 2 - 7 } & Test ADF & VCM 5\% & Decision & Test ADF & VCM 5\% & Decision \\
\hline Log GDP & -2.0542 & -3.5529 & NS & -4.5059 & -3.5577 & I(1) \\
Log INV & -3.2498 & -3.5403 & NS & -9.5106 & -3.5442 & I(1) \\
Log CG & -2.0065 & -3.5529 & NS & -6.0754 & -3.5628 & I(1) \\
IT & -2.6808 & -3.5333 & NS & -6.1131 & -1.9506 & I (1) \\
INFL & -3.3014 & 0.0847 & NS & -10.464 & -3.5577 & I (1) \\
Log IRP & -1.3167 & -3.5683 & NS & -4.8267 & -3.6328 & I (1) \\
\hline
\end{tabular}

Source: Authors' calculations.

The results of the unit root tests indicate that the statistics of the test at level allow us to accept the null hypothesis of non stationarity for the whole of the variables at the threshold of $5 \%$. They show that for all variables concerned, the data are stationary in first difference.

\subsection{Test of Cointegration}

\subsubsection{Determination of Number of Lags}

The problem of optimal lag is important because it gives us the average duration of response variables. The calculation of information criteria for delays ranging from 1 to 3 (we will not further given the low number of observations) gives the following results: These criteria are based on the contribution of information generated by additional delays in the model.

Table 2. Selecting the number of lags

\begin{tabular}{cllll}
\hline Lag & FPE & AIC & SC & HQ \\
\hline 0 & $7.29 \mathrm{e}-08$ & 0.592346 & 0.880310 & 0.677973 \\
1 & $2.40 \mathrm{e}-10$ & -5.196990 & $-3.181244^{*}$ & -4.597603 \\
2 & $1.77 \mathrm{e}-10$ & -5.950492 & -2.206963 & -4.837345 \\
3 & $9.12 \mathrm{e}-11^{*}$ & $-8.141847^{*}$ & -2.670535 & $-6.514939^{*}$ \\
\hline
\end{tabular}

Source: Authors' calculations.

The table above shows us that the criteria of information are minimized in the third shift. Accordingly, the analysis will be conducted on a VECM (2).

\subsubsection{Choice of the Best Model}

A long-term relationship between several variables exists if two conditions are fulfilled. First, the variables must be non-stationary and integrated into the same order. Secondly, their stochastic trends must be linked.

In 1991 and 1995, Johansen has proposed a multivariate approach based on the method of maximum likelihood. 
It is used to check the cointegration of series by a test of the rank of cointegration.

The completion of the test for cointegration will occur through two main tests including the test of the trace and the test of the value of its own maximum. The purpose of these tests is to determine the cointegration number between the variables in the model.

In the estimates, the determination of the cointégration number is necessary to identify the shape of the Error Correction Model to use. The literature provides in effect five types of relations or models of cointegration including:

- The cointegration relationship without trend and without intercept (model 1);

- The cointegration relationship without trend and with intercept (model 2);

- The relationship (linear) without trend and with intercept (model 3);

- The relationship (linear) with trend and intercept (model 4);

- The relationship (quadratic) with trend and intercept (model 5);

To know which specification we must select, it is necessary to resort to the stationarity tests made previously. These tests consider the presence of a linear trend in the level of some series. Therefore, we realize the cointegration test in a context where the constant is not constrained, but where the linear trend is forced to appear only in the cointegration space.

The following table presents the results of the test from the best model chosen.

Table 3. Johansen's test

\begin{tabular}{ccccc}
\hline $\begin{array}{c}\text { Hypothesized } \\
\text { No. of this(s) }\end{array}$ & Eigenvalue & $\begin{array}{c}\text { Trace } \\
\text { Statistic (Note1) }\end{array}$ & $\begin{array}{c}0.05 \\
\text { Critical Value }\end{array}$ & Prob.** \\
\hline None $*$ & 0.927990 & 208.3542 & 103.8473 & 0.0000 \\
At most $1 *$ & 0.901682 & 137.3186 & 76.97277 & 0.0000 \\
At most $2 *$ & 0.663699 & 74.69067 & 54.07904 & 0.0003 \\
At most $3 *$ & 0.575341 & 45.26744 & 35.19275 & 0.0030 \\
At most $4 *$ & 0.390009 & 22.14281 & 20.26184 & 0.0272 \\
At most 5 & 0.278046 & 8.796427 & 9.164546 & 0.0587 \\
\hline
\end{tabular}

Source: Authors' calculations.

The results of the tests of the trace allow us to conclude that there is at least a cointegrating relation.

\subsection{Estimation of the Model}

The Error Correction Model shows the common cointegration relation (the common tendency) and deducts the interactions between the variables (Note 2). It allows to model jointly the dynamics of short term (represented by the variables in first difference) and long term (represented by the variables in level).

Table 4. Estimate of the cointegration vector

\begin{tabular}{|c|c|c|c|c|c|c|}
\hline \multicolumn{7}{|c|}{ The coefficients of the long-term relationship } \\
\hline $\log \operatorname{GDP}(-1)$ & $\log \operatorname{INV}(-1)$ & $\log G C(-1)$ & $\log \operatorname{IRP}(-1)$ & $\operatorname{INFL(1)}$ & $\operatorname{IT}(-1)$ & $\mathrm{C}$ \\
\hline & -0.70447 & 0.39824 & -0.20911 & 0.10202 & 0.10866 & \\
\hline 1.0000 & {$[-9.0870]$} & [1.4626] & {$[-2.2012]$} & [12.414] & [7.0682] & -14.9857 \\
\hline \multicolumn{7}{|c|}{ The coefficients of error correction mechanism } \\
\hline-0.271182 & -0.223506 & 0.018180 & -0.044294 & -1.130607 & 0.157147 & \\
\hline$[-5.61275]$ & {$[-1.31559]$} & {$[0.05146]$} & {$[-0.26691]$} & {$[-0.24476]$} & [0.11018] & \\
\hline
\end{tabular}

Source: Authors' calculations.

The normalization in relation to the variable LGDP allows to rewrite the long term equation in the following form:

$$
\log G D P=14.985+0.704 \log I N V-0.398 \log G C+0.209 \operatorname{LogIRP}-0.088 \text { INFL }-0.099 \text { IT }
$$

The analysis of the results obtained, shows us that the term of Error Correction Model $(-0.2711)$ is negative and 
lower than the unit. There is therefore an error correction mechanism: in the long term, the imbalances between the variables are compensated so that the series have similar developments.

We can to this effect validate the model and interpret without concern, the long-term relationship.

The interpretation of these results is based on the analysis of the signs of the coefficients of the long term equation:

Public investment expenditures have a positive impact on the long-term growth: In effect, the impact has been positive and significant in the long term. This result corroborates with the Keynesian thesis, which shows the importance of the budget policy. Public expenditures are considered as the engines of growth.

Government consumption has a negative impact on the growth of the Moroccan economy. A priori, public consumption spending fuelling demand and cause, through the multiplier effect Keynsian, a short-term growth of GDP. Nevertheless, in an open economy, the impact of the multiplier effect on the growth is even lower than the marginal propensity to import of the economy is high. This could explain a part of the impact negative overall long-term government consumption on growth.

The long term elasticity of the gross domestic product compared to the index of governance IRP is equal to 0.209. That is, if the governance in Morocco improves by one unit, real GDP will increase by 0.209 . Here are therefore, the major implications to invest in the practices of good governance (improving the quality of democratic institutions, private property rights institutions, and particularly the regulatory institutions, combating corruption, limiting policymakers rent capture behavior favorable to the sustainability of economic growth in the country). Our results, like almost all empirical studies show that this variable plays a crucial role in the growth.

Economic growth depends negatively to the rate of inflation. The rate of inflation in Morocco has ambivalent relations with the rate of growth. Indeed, the non-negligible proportion of the agricultural production in the composition of the total supply in the Moroccan economy and the deflationary impact on the foodstuffs generally exercised by a good agricultural campaign, justify the assumption of an inverse relationship between global supply and inflation.

The elasticity of the long term of the gross domestic product compared to the rate of interest is - 0.099 , this implies that in the long term, if the interest rate increases of $10 \%$, then the GDP decreases of $0.9 \%$.

\subsection{Impulse Responses Functions}

The analysis of the impulse responses functions will allow us to visualize the impacts of the variation of a variable on the other. In other words, up to what point the fluctuations of a given variable are attributable to variations of each variable in the model. On this level, we used the technique of the functions of impulse responses cumulative orthogonal (FRIC) of variables used in our model as a result of a positive shock to the variable "Investment". According to this technique of forecast, that we chose to project over 5 years, the rate of economic growth gains more than $11 \%$ during the five years following the shock, the government consumption, the index of risk policy and inflation increase respectively by $3 \%, 3.9 \%$ and $1.8 \%$, while recording a decrease in the rate of interest of almost 5.4 points.

Table 5. Impulse responses functions IRF of the model

\begin{tabular}{rccccr}
\hline Period & Log GDP & Log GC & INFL & Log IRP & IT \\
\hline 1 & 0.000000 & 0.000000 & 0.000000 & 0.000000 & 0.000000 \\
2 & 0.024959 & 0.008847 & 0.177887 & 0.017334 & -0.084473 \\
3 & 0.028167 & 0.014461 & 0.196075 & 0.019038 & -0.054723 \\
4 & 0.072790 & 0.017623 & 0.414503 & 0.011266 & -0.123265 \\
5 & 0.113494 & 0.030071 & 0.183344 & 0.039292 & -0.054695 \\
\hline
\end{tabular}

Source: Authors' calculations.

\section{Conclusion}

The object of this study was to evaluate the relative effectiveness of the budgetary policy using the Error Correction Model following the Johansen's approach. The analysis of the long-term elasticity shows that the effects of the budgetary policies influence the economic growth. The governance measures and reforms that the Moroccan Government has applied, whether it is monetary or fiscal policy, have contributed to move the growth.

The fiscal policy, apprehended by the expenditure, is effective in the long term. It has been identified that the governance component remains a best option in which Morocco will have to invest, as it provides long-term 
benefits at low costs in the face of its enormous productive potential.

Overall, good governance improves the effectiveness of the budgetary policy and exerts a positive and significant effect on economic activity in Morocco.

\section{References}

Ayadi, E. (2002). Politique Budgétaire, Ajustement et Croissance Economique: application au Cas de la Tunisie. Thèse de Doctorat en Sciences Economiques, Université de Nice, décembre, 2 tomes, p. 506.

Baldacci, E., Clements, B. \& Gupta S. (2003), Utiliser la politique budgétaire pour stimuler la croissance. Finance et Développement, FMI, 28-31. Retrieved from https://www.imf.org/external/pubs/ft/fandd/fre/2003/12/pdf/baldacci.pdf

Baldacci, E., Hillman, A., \& Kojo, N. (2003). Growth, governance, and fiscal policy in Low-Income Countries: Understanding the transmission channels. IMF Working Paper. Retrieved from https://www.imf.org/external/pubs/ft/wp/2003/wp03237.pdf

Barro, R. J. (1990). Government spending in a Simple Model of Endogenous Growth. Journal of Political Economy, 98. https://doi.org/10.1086/261726

Blanchard, O. J., \& Quah, D. (1988). The dynamic effect of aggregate demand and supply disturbances. National Bureau of Economic Research, no 2727. https://doi.org/10.3386/w2737

Forte, F., \& Magazzino, C. (2011). Optimal Size Government and Economic Growth in EU Countries. Economia Politica-Journal of Analytical and Institutional Economics, XXVIII(3), 295-321

Guellec, D., \& Ralle P. (1997). Les nouvelles théories de la croissance. La Découverte, collection Repères, Paris.

Kaufman, D., Kraay, A., \& Mastruzzi, M. (2010). The Worldwide Governance Indicators: Methodology and Analytical Issues. Policy Research Working Papers. https://doi.org/10.1596/1813-9450-5430

Keynes, J. M. (1936). Théorie générale de l'emploi, de l'intérêt et de la monnaie. Traduction française de Largentaye J., Payot, (1982). Retrieved from http://www.uqac.cal

Magazzino, C. (2012). Wagner versus Keynes: Public Spending and National Income in Italy at a Disaggregated Level. Journal of Policy Modeling, 34(6), 890-905. https://doi.org/10.1016/j.jpolmod.2012.05.012

Magazzino, C. (2014). Government size and economic growth in Italy: An empirical analysis based on new data (1861-2008). International Journal of Empirical Finance, 3(2), 38-54

\section{Notes}

Note1.The statistics of the test is the trace statistics which is defined as: $Q_{r}=-T \sum_{i=r+1}^{k} \log \left(1-\lambda_{i}\right)$ With $\mathrm{T}=$ number of observations; $\lambda=$ value own

Note 2. Bourbonnais, "Econometrics", 6th edition, Dunod, Paris, 2005, p. 279.

\section{Appendix A}

\section{Graphic representation of the variables}
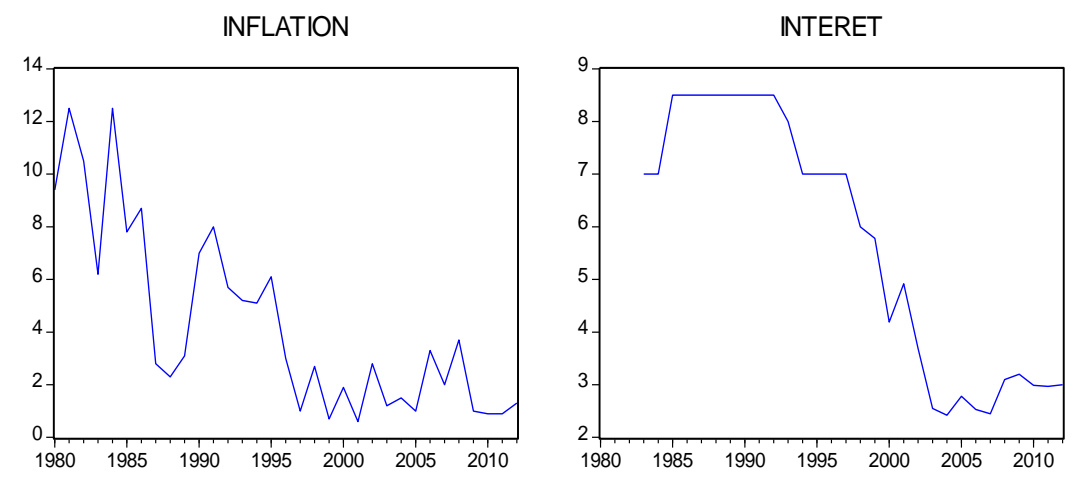

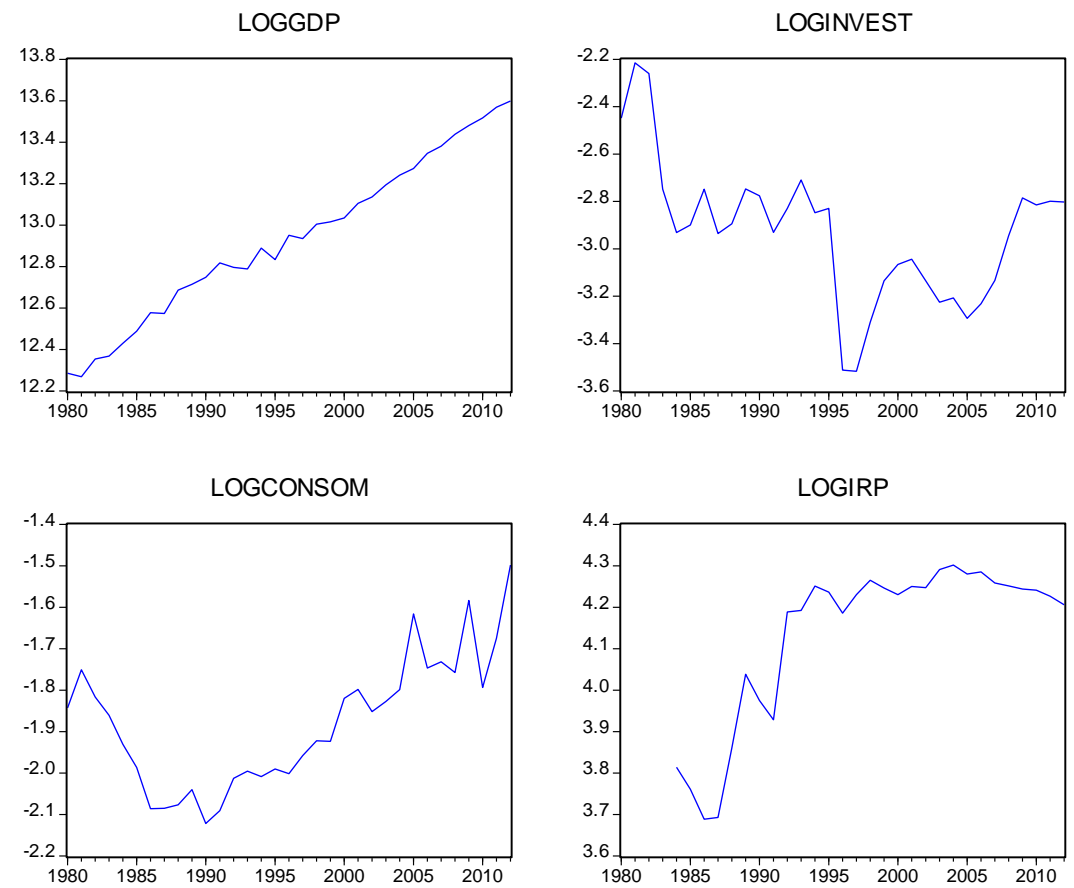

\section{Appendix B}

\section{Stability of the model}

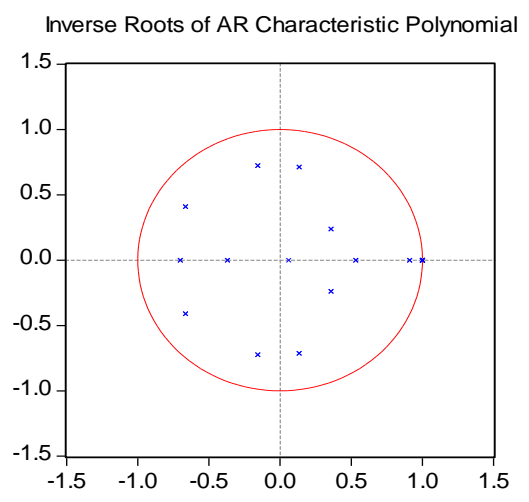

\section{Copyrights}

Copyright for this article is retained by the author(s), with first publication rights granted to the journal.

This is an open-access article distributed under the terms and conditions of the Creative Commons Attribution license (http://creativecommons.org/licenses/by/4.0/). 